\title{
Does rock type account for variation in mussel attachment strength? A test with Brachidontes rodriguezii in the southwestern Atlantic
}

\author{
Jorge L. Gutiérrez ${ }^{1,2^{*}}$, María Bagur ${ }^{1,3}$, Lorena P. Arribas ${ }^{4}$ and M. Gabriela Palomo ${ }^{1,3}$
}

\begin{abstract}
Mussel attachment strength varies in space and time, frequently in association with variations in wave exposure. Yet, it remains uninvestigated whether different rock types can contribute to variation in mussel attachment. Here we compared the attachment strength of the mussel Brachidontes rodriguezii between soft and hard intertidal rock substrates that are typical of coastal Buenos Aires Province, Argentina: Pampean loess cemented by calcium carbonate and orthoquartzite, respectively. Overall comparisons of mussel attachment across natural platforms of either rock type (10 loess sites and 4 orthoquartzite sites) indicated stronger mussel attachment to orthoquartzite. However, mussel attachment strength did not differ when compared across natural loess platforms and introduced orthoquartzite blocks (i.e., groins and revetments) occurring within the same site. Mussels attaching to loess showed more byssal threads than those attaching to orthoquartzite at the same site. These findings suggest, first, that rock type does not influence mussel attachment strength in our study system, secondly, that overall differences in mussel attachment strength with rock type across natural platforms in our study range are due to confounding influences of co-varying factors (e.g., wave exposure) and, finally, that mussels can increase byssus production to counteract potential substrate failure when attaching to soft, friable rock. The latter likely explains the ability of mussels to maintain relatively stable cover across rocks of contrasting hardness.
\end{abstract}

Keywords: Mussel, Attachment, Dislodgement, Rock, Orthoquartzite, Loess, Hardness, Friability

\section{Background}

Sessile and low-mobile organisms inhabiting rocky shores and reefs (e.g., algae, barnacles, mussels, gastropods, echinoids) rely on their morphology and adhesion mechanisms to withstand wave action [1]. When the hydrodynamic forces acting on these organisms (i.e., a function of their size, shape, and flexibility) exceed the strength to which they are attached to the substrate, they become dislodged [1-3] and usually die [but see 4,5]. Attachment strength in sessile or low-mobile intertidal

\footnotetext{
*Correspondence: jgutierrez@grieta.org.ar

${ }^{1}$ Grupo de Investigación y Educación en Temas Ambientales (GrlETA), Estación Biológica Las Brusquitas, B7783ADE San Eduardo del Mar, Argentina

Full list of author information is available at the end of the article
}

organisms has been observed to vary in time and space [6-10]. These variations are frequently associated with differences in wave exposure, with attachment strength increasing as exposure increases $[6,8,9]$. Although physi$\mathrm{cal}$ and chemical substrate properties (such as roughness, hardness, free energy, and polarity) are known to affect organismal adhesion and persistence [11, 12], it remains largely uninvestigated if variation in rock type accounts for spatial variation in the attachment strength of sessile organisms.

Just a few studies on algae have addressed relationships between organismal attachment strength and substrate type in rocky shores and reefs $[9,13,14]$. They suggest that algal attachment is generally weaker on soft relative to hard substrates. For instance, Thomsen et al. [9] observed that the kelp, Ecklonia radiata, attaches more 
strongly to hard (granite, sandstone) than soft rock (limestone), and that thalli attached to soft rock are more often dislodged due to substrate failure (vs. breakage at the stipe-thallus junction or thallus). This suggests that the probability of kelp dislodgement increases with decreasing substratum hardness and increasing friability (i.e., the potential of rocks to break and disaggregate into smaller pieces). However, it is unknown whether rock hardness and friability can also affect the potential for dislodgement of sessile rocky shore invertebrates. Mussels, for instance, attach to the substrate by means of collagenous threads secreted by the byssal gland located in the foot [12], and may either be dislodged due to thread failure, substrate failure, or both $[3,15]$. From the above findings in algae, we could preliminary predict that mussels in soft, friable rock would face increased risk of dislodgement due to increased potential for substrate failure. Nevertheless, Bell and Gosline [3] suggested that mussels could increase their attachment strength in friable substrates and reduce their risk of dislodgement by producing more and thicker byssal threads. Mussels are known to increase byssus production to strengthen their attachment in response to increased flow severity [3, 8, $16,17]$. Yet, it remains unclear whether they can do so in response to rock friability so as to counteract potential substrate failure.

Brachidontes rodriguezii is a relatively small intertidal mussel (up to $55 \mathrm{~mm}$ length, most individuals less than $30 \mathrm{~mm}$ length) that occurs from Rio Grande, Brazil $\left(32^{\circ} \mathrm{S}\right)$ to Punta Ninfas, Argentina $\left(43^{\circ} \mathrm{S}\right)$ [18]. It attaches to rocks of varying composition and hardness [19-22] as well as conspecifics [22], other bivalves [23], empty mollusk shells [24], coarse sand [25], and human-made coastal structures such as jetties, groins and pier pilings $[26,27]$. This species forms dense (up to 2000 ind $\mathrm{dm}^{-2}$ ) and nearly monospecific beds in the mid intertidal zone of rocky shores in Buenos Aires province, Argentina $\left(37-41^{\circ} \mathrm{S}\right)[19,20]$. These beds are primarily singlelayered [22] and serve as habitat to a myriad of other invertebrates and algae [19-21, 26]. Soft, friable rock of Pliocene-Pleistocene origin (Pampean loess cemented by calcium carbonate) is the most widespread natural intertidal substrate for this species in Buenos Aires province, with the noticeable exception of outcrops of hard Ordovicic orthoquartzite that occur by the city Mar del Plata $\left(38^{\circ} \mathrm{S}\right)[28]$.

In a previous study [22] we observed weaker attachment strength of $B$. rodriguezii in a soft rock site than in a hard rock one. However, these sites were sampled at different times of the year, which suggests that the comparison of mussel attachment strength among rock types might be confounded by the effect of sampling date (i.e., due to temporal variations in mussel attachment strength) $[7,8,29]$. Therefore, in this study we compared mussel attachment strength across a series of loess and orthoquartzite shore sites, which were sampled within narrow time frames (5 days) to avoid confounding influences of sampling time. Moreover, we compared mussel attachment strength in loess and orthoquartzite at sites were both substrates co-occur to avoid confounding the effects of rock type with other factors that may covary among sites (e.g., wave exposure) [4]. Additionally, we compared the location of byssus failure (i.e., byssal threads and/or substrate) and the number and thickness of byssal threads in mussels detached from loess and orthoquartzite in order to explore potential mechanisms relating attachment strength to rock type. Finally, we discuss whether the observed attachment strength values can warrant attachment under realistic flow forces and briefly outline potential implications variations in rock type for the stability of mussel beds and intertidal loess habitats.

\section{Methods \\ Study area}

Mussel attachment strength was measured at 14 rocky intertidal sites located across a ca. $80 \mathrm{~km}$ coastal range between the towns of Santa Clara del Mar $\left(37^{\circ} 50^{\prime} \mathrm{S}\right.$, $\left.57^{\circ} 30^{\prime} \mathrm{W}\right)$ and Mar del Sur $\left(38^{\circ} 20^{\prime} \mathrm{S}, 57^{\circ} 59^{\prime} \mathrm{W}\right.$; both in Buenos Aires Province; Fig. 1, Table 1). Pliocene-Pleistocene loess and Ordovicic orthoquartzite are the natural substrates at 10 and 4 of these sites, respectively (Fig. 1, Table 1). In addition, human-introduced orthoquartzite blocks occur adjacent to natural loess platforms at 3 of these sites (Fig. 1, Table 1). They were placed for coastal protection purposes, either forming groins (i.e., structures that extend from the beach backshore into the surf zone, perpendicular to the shoreline so as to intercept the longshore drift; see Chapadmalal and Copacabana in Fig. 1 and Table 1) or revetments (i.e., shoreline-based and, thus, shore-parallel structures built to counteract wave energy and prevent coastline retraction; see Frente Mar in Fig. 1 and Table 1) [see 28].

Measures of relative rock hardness, surface friability, and wave exposure are also included in Table 1 . To measure rock hardness and friability, 4-5 rock fragments were collected from each site using hammer and chisel and left dry outdoors during 3 sunny days. Rock hardness was measured as the inverse of the mean depth $(\mathrm{mm})$ of 4 replicate holes ( $4 \mathrm{~mm}$ diameter) drilled during $30 \mathrm{~s}$ with a power drill [30]. No pressure was applied on the drill by the operator. Rock friability was measured as the weight per area unit $\left(\mathrm{mg} \mathrm{cm}^{-2}\right)$ of particles detached from the rock surface by three squared, ca. $5 \mathrm{~cm}$ side pieces of duct tape. A duct tape piece was fastened to an exposed portion of the rock surface (i.e., not covered by mussels 


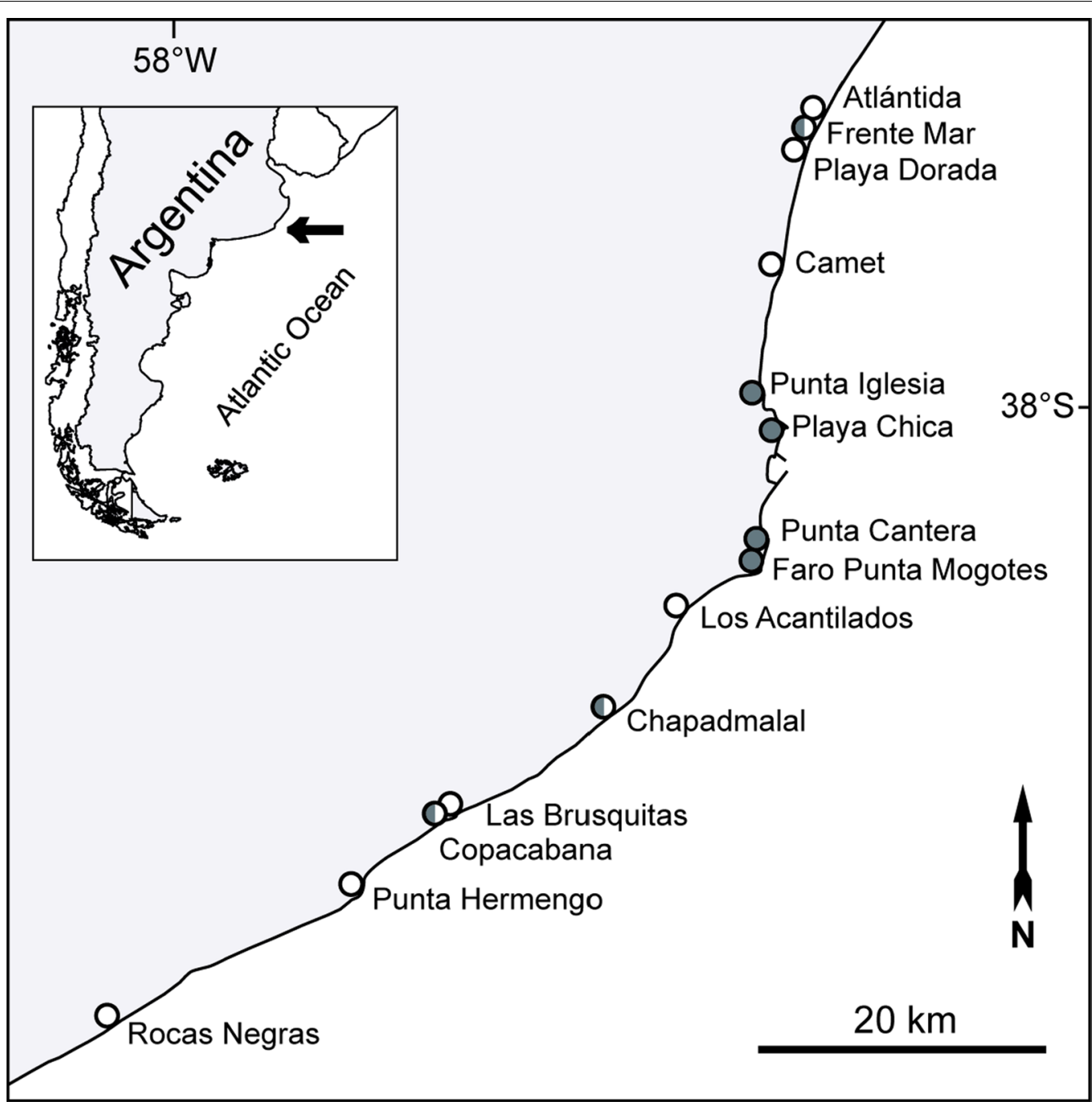

Fig. 1 Study sites. Substrate types are loess cemented by calcium carbonate (soft rock, open circles), orthoquartzite (hard rock, filled circles), natural loess platforms and orthoquartzite blocks introduced to form groins or revetments (half-filled circles)

or other organisms) in each of three rock fragments and then removed. The weight of particles removed by tape pieces per area unit was calculated as the weight per area unit of tape pieces that were fastened to rocks minus the weight per area unit of tape pieces without previous use. As a measure of wave exposure, we calculated the mean slope (\%) from the sampling point to the $5 \mathrm{~m}$ isobath in the Southeast direction-i.e., the average direction of strong swells [31]—using nautical charts.

\section{Mussel attachment strength}

Measurements of attachment strength were carried out at all the above-mentioned sites and their substrates during two restricted time periods: May 11-15, and November $8-12$, 2015. To ensure that comparable tidal levels were sampled at each site, samplings were restricted to the upper $3 \mathrm{~m}$ fringe of the mussel zone, where mussel cover is generally patchy (cf. continuous cover lower in the intertidal slope). The mussels studied at sites with both natural loess platforms and introduced orthoquartzite blocks were all located within a $10 \mathrm{~m}$ radius to minimize variation in factors other than rock type. Moreover, when comparing mussel attachment between orthoquartzite groins and natural loess platforms we sampled at the downdrift side of groins and their downdrift loess platforms to ensure similar orientation and exposure (see Additional file 1).

Mussel attachment strength (i.e., the force necessary for detachment) was measured using spring dynamometers equipped with a drag pointer to record maximum force [32]. Mussels in horizontal rock surfaces $(n=12$ at each site and date) were clung to the spring dynamometer 
Table 1 Study site coordinates and rock type/s. Measures of relative rock hardness, surface friability, and wave exposure (SE slope) are also included (see footnotes for description and "Study Area" section for methods)

\begin{tabular}{|c|c|c|c|c|c|c|}
\hline Site & Latitude (S) & Longitude (W) & Rock type & Hardness $^{\mathrm{a}}$ & Friability $^{\mathbf{b}}$ & SE slope \\
\hline Atlántida & $37^{\circ} 51^{\prime} 06^{\prime \prime}$ & $57^{\circ} 30^{\prime} 21^{\prime \prime}$ & $P L$ & 0.05 & 6.56 & 0.73 \\
\hline Frente Mar & $37^{\circ} 51^{\prime} 30^{\prime \prime}$ & $57^{\circ} 30^{\prime} 32^{\prime \prime}$ & $\mathrm{PL} / \mathrm{OO}(\mathrm{I})$ & $005 / 0.67$ & 7.73 & 0.71 \\
\hline Playa Dorada & $37^{\circ} 52^{\prime} 18^{\prime \prime}$ & $57^{\circ} 30^{\prime} 53^{\prime \prime}$ & $P L$ & 0.07 & 4.53 & 0.72 \\
\hline Camet & $37^{\circ} 56^{\prime} 04^{\prime \prime}$ & $57^{\circ} 31^{\prime} 52^{\prime \prime}$ & $P L$ & 0.04 & 8.89 & 0.63 \\
\hline Punta Iglesia & $37^{\circ} 59^{\prime} 48^{\prime \prime}$ & $57^{\circ} 32^{\prime} 27^{\prime \prime}$ & $\mathrm{OO}$ & 0.67 & 0.48 & 1.7 \\
\hline Playa Chica & $38^{\circ} 01^{\prime} 16^{\prime \prime}$ & $57^{\circ} 31^{\prime} 38^{\prime \prime}$ & $\mathrm{OO}$ & 0.57 & 0.92 & 2.02 \\
\hline Punta Cantera & $38^{\circ} 04^{\prime} 51^{\prime \prime}$ & $57^{\circ} 32^{\prime} 08^{\prime \prime}$ & $\mathrm{OO}$ & 0.67 & 0.84 & 1.06 \\
\hline Faro Punta Mogotes & $38^{\circ} 05^{\prime} 36^{\prime \prime}$ & $57^{\circ} 32^{\prime} 28^{\prime \prime}$ & $\mathrm{OO}$ & 0.8 & 0.95 & 1.7 \\
\hline Los Acantilados & $38^{\circ} 07^{\prime} 28^{\prime \prime}$ & $57^{\circ} 35^{\prime} 56^{\prime \prime}$ & $\mathrm{PL}$ & 0.03 & 1.41 & 0.81 \\
\hline Chapadmalal & $38^{\circ} 11^{\prime} 02^{\prime \prime}$ & $57^{\circ} 39^{\prime} 14^{\prime \prime}$ & $\mathrm{PL} / \mathrm{OO}(\mathrm{I})$ & $0.07 / 0.67$ & 6.87 & 0.74 \\
\hline Las Brusquitas & $38^{\circ} 14^{\prime} 43^{\prime \prime}$ & $57^{\circ} 46^{\prime} 33^{\prime \prime}$ & $P L$ & 0.04 & 8.17 & 0.79 \\
\hline Copacabana & $38^{\circ} 14^{\prime} 50^{\prime \prime}$ & $57^{\circ} 46^{\prime} 50^{\prime \prime}$ & $\mathrm{PL} / \mathrm{OO}(\mathrm{I})$ & $0.05 / 0.57$ & 7.14 & 0.79 \\
\hline Punta Hermengo & $38^{\circ} 17^{\prime} 14^{\prime \prime}$ & $57^{\circ} 50^{\prime} 12^{\prime \prime}$ & $P L$ & 0.09 & 3.79 & 1.11 \\
\hline Rocas Negras & $38^{\circ} 21^{\prime} 53^{\prime \prime}$ & $58^{\circ} 01^{\prime} 16^{\prime \prime}$ & $P L$ & 0.15 & 2.27 & 1.01 \\
\hline
\end{tabular}

PL, Pliocene-pleistocene loess cemented by calcium carbonate; OO, Ordovicic orthoquartzite; OO(I), human-introduced Ordovicic Orthoquartize (groins and revetments)

a Inverse of the mean depth $(\mathrm{mm}$ ) of 4 replicate holes (4 $\mathrm{mm}$ diameter) drilled during $30 \mathrm{~s}$ with a power drill [42]

b Weight per area unit $\left(\mathrm{mg} \mathrm{cm}^{-2}\right)$ of particles detached from the rock surface by three squared, $\mathrm{ca} .5 \mathrm{~cm}$ side pieces of duct tape

c Mean slope (\%) from the sampling point to the $5 \mathrm{~m}$ isobath in the Southeast direction (the average direction of strong swells) estimated from nautical charts

(Pesola ${ }^{\circledR} ; 1000$ g capacity) by means of a crocodile clump. Force was applied perpendicular to the substrate until the mussel was dislodged. All the mussels analyzed were within the same size range (15-20 mm length, which is the modal size class in our rocky intertidal sites; see [22]) and were sampled from the interior of mussel patches ( $>20 \mathrm{~cm}$ from the patch edge) to avoid potentially confounding influences of size and position within the bed on mussel attachment strength [7,33]. We considered mussels that were relatively distant from each other $(50 \mathrm{~cm}$ or more) to ensure that measurements were not affected by the previous pulling of neighboring individuals. We excluded from this analysis those cases where additional mussels were removed together with the one attached to the dynamometer, which usually comprised less than $5 \%$ of all measurements [22].

Mussel attachment strength was compared between natural loess and orthoquartzite substrates (i.e., global comparison, attachment data from loess and orthoquartzite pooled across sites) and between natural loess and introduced orthoquartzite at the 3 sites where they co-occur (i.e., local comparison). Global differences in mussel attachment strength between rock types were evaluated with a randomization test [34]. Here, the difference in the mean attachment strength of mussels in loess (10 sites pooled) and orthoquartzite (4 sites pooled) was calculated $\left(D_{0}\right)$. Then, the attachment strength data from each site was randomly assigned to either rock type so that 10 are assigned to loess and 4 are assigned to orthoquartzite, and the difference between the means of the two groups was calculated $\left(D_{1}\right)$. This last step was iterated 1000 times and the proportion of all the $D_{i}$ s that are greater than or equal to $D_{0}$ (i.e., the difference between the means in our samples) was considered as the $P$ value [see 35 for an analogous example]. Separate randomization tests were conducted for the May 2015 and November 2015 data. This method was chosen instead of traditional ANOVA because the unbalanced number of sites from each rock type prevents the construction of exact $F$-ratios (their sum will differ from 1 under the null hypothesis) and, thus, the probability associated to observed $F$-values will differ from tabulated values [see 36].

Local differences in the attachment strength of mussels to loess and orthoquartzite were evaluated with a three-way mixed model ANOVA [35] with Rock Type (natural loess vs. introduced orthoquartzite blocks) as fixed factor, and sampling date and site as random factors. The assumptions of normality and homoscedasticity were evaluated with Shapiro-Wilk's and Levene's tests, respectively [36, 37]. Attachment strength data were transformed to their natural logarithm to meet the assumption of homoscedasticity [36; see Additional file 2]. 


\section{Byssal thread counts and failure locations}

Mussels attaching to loess and orthoquartzite (15$20 \mathrm{~mm}$ length, $\mathrm{n}=15$ ) were collected on April 25, 2018, from a single site (Copacabana, see Fig. 1, Table 1) to test if the location of attachment failure and the number and thickness of byssal threads varies with rock type. Mussels for byssus analysis were detached by hand, fixed in alcohol, carried to the laboratory, and observed under a stereoscopic dissection microscope (Leica MZ9.5). Byssal threads were counted and their location of failure classified as substrate (rock, adhesive plaque, sand grains or shell fragments) or byssus [2]. Due to imprecision inherent to the quantification of thin, numerous, and often entangled byssal threads, their counts were approximated to the nearest 5 (see also [3]). The thickness of 5 byssal threads per mussel was measured with a graduated ocular using the highest magnification $(60 \times)$. Such measurements had a precision of $16.5 \mu \mathrm{m}$, which allowed classifying threads within four thickness categories: 16.5-33, 33-49.5, and 49.5-66, 66-82.5 $\mu \mathrm{m}$. Complementary measurements of mussel attachment strength on each rock type at this site were carried out on April 26, $2018(n=33$, same methods as above) to assess how it relates to variation in byssal thread attributes. Student's $t$ tests [37] were used to analyze differences between rock types in mussel attachment strength, the mean number of byssal threads per mussel, and the mean proportion of each failure location per mussel. As above, the assumptions of normality and homoscedasticity were evaluated with Shapiro-Wilk's and Levene's tests, respectively [36, 37]. The number of byssal threads per mussel and the proportion of adhesive plaque failures were ln-transformed to meet the assumption of homoscedasticity [36; see Additional file 3]. A Chi squared test [37] was used to evaluate if threads of mussels from loess and orthoquartzite differ in their distribution across our four thickness categories.

\section{Results}

\section{Mussel attachment strength}

Mussels showed stronger attachment in orthoquartzite than loess when measurements were globally averaged across sites (Fig. 2a). The difference between the mean mussel attachment strength of mussels in orthoquartzite and loess was significantly higher than the expected if sites are randomly assigned to each rock type (Fig. 2, Table 2).

On the other hand, local comparisons indicated no variation in mussel attachment strength with rock type (Fig. 3, Table 3). In this case, the interaction between sampling date and site was the only significant effect (Table 3).

\section{Byssal thread counts and failure locations}

The dislodgement of mussels from either rock type resulted from a combination of byssus and substrate failures. Byssus failures occurred at the level of the thread themselves (root failures were not observed, though the latter may have been overlooked as they are hard to locate; see [3]). Substrate failures were far more common (ca. $70 \%$ of threads per individual; Fig. 4c) and can either be attributable to adhesive plaque detachment (i.e., no material was observed adhered to the plaque), breakdown of the basal rock substrate (i.e., either loess or orthoquartzite adhered to the plaque), or adhesion to loose particles (i.e., sand or beach shell fragments adhered to the plaque). All four failure locations (i.e., thread, plaque, rock, loose particles) were observed in each of the individual mussels sampled.

Mussels from loess showed more byssal threads than those from orthoquartzite (Table 4; Fig. 4a) but no concurrent differences in mussel attachment strength were observed (Table 4; Fig. 4b). The thickness frequency distribution of byssal threads did not differ between rock types (Chi square test: $x^{2}=1.60, d f=3, P=0.66$ ). The proportion (and number) of rock failures was larger in mussels from loess than orthoquartzite (Table 4; Fig. 4c). Mussels from orthoquartzite, on the other hand, showed a larger proportion of plaque and loose particle failures than those from loess (Table 4; Fig. 4c).

\section{Discussion}

\section{Mussel attachment strength}

There is apparent contradiction in the outcomes of global and local comparisons of mussel attachment strength across rock types. Mussels showed stronger attachment in orthoquartzite than loess when measurements are globally averaged across sites (see Fig. 2a). However, mussel attachment strength did not differ across rock types at sites where orthoquartzite and loess co-occur (i.e., local comparisons; see Fig. 3). Here we argue that local comparisons provide a reliable test of rock type effects on mussel attachment, as they were conducted within a restricted spatial extent at each site $(10 \mathrm{~m}$ radius; see "Methods" section) which allowed keeping to a minimum any variation in factors other than rock type. Therefore, we conclude that variations in mussel attachment strength across our entire study range (see Fig. 2b) are unrelated to rock type. Meanwhile, the observed interaction between site and sampling date (see Table 3) suggests that temporal variation in attachment strength is not spatially synchronized, possibly due to site-specific variations in environmental factors and/or 
a

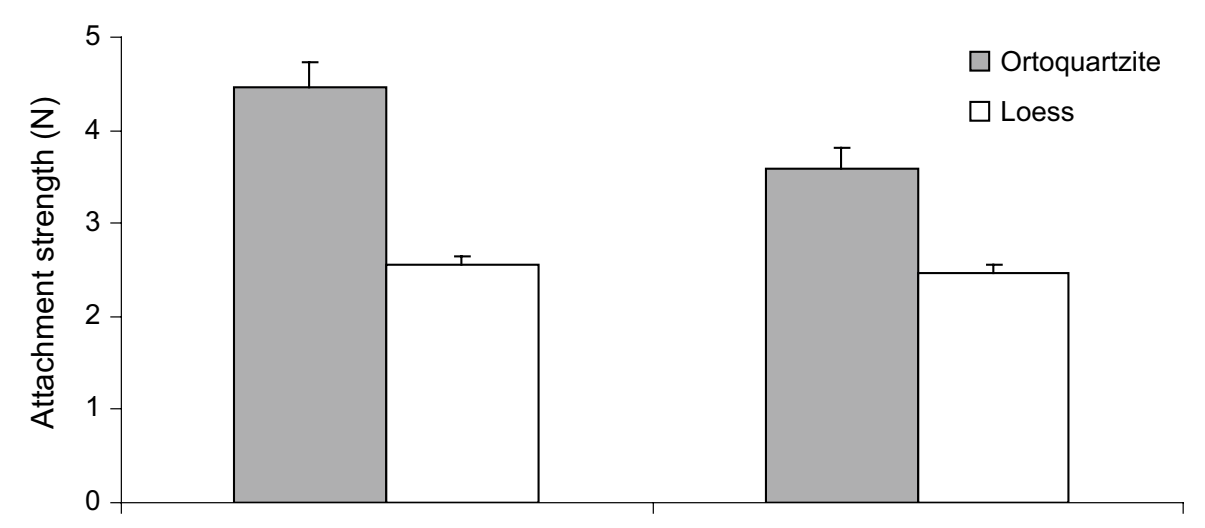

May 2015



Fig. 2 Mean (SE) attachment strength of Brachidontes rodriguezii in a orthoquartzite and loess cemented by calcium carbonate (sites pooled, $n=48$ and 120 , respectively) and $\mathbf{b}$ across rocky intertidal sites $(n=12)$

mussel physiological status-e.g., asynchrony in mussel reproductive condition, which may affect the allocation of energy to byssus production [8].

Since mussel attachment strength does not vary with rock type at the local scale (i.e., where variations in factors other than rock type is likely minimum), global variations in mussel attachment strength with rock type across natural platforms should be attributed to confounding influences of co-varying factors. Wave exposure is perhaps the most obvious, potentially confounding variable in this study system. Indeed, mussels attach more strongly at sites with stronger wave action $[32,38]$, meanwhile wave exposure also positively covaries with the hardness of natural rocky substrates [4]. While we did not quantify wave exposure in this study, orthoquartzite sites are distributed along headlands (see Fig. 1), show relatively steep slopes (Table 1) and, thus, are expected to receive more wave energy-e.g., 
Table 2 Results of randomization tests comparing the observed differences $\left(D_{0}\right)$ in mean attachment strength between mussels occurring in natural orthoquartzite and loess platforms (sites pooled) with the difference in mean attachment strength when sites are randomly assigned to either rock type $\left(D_{i}\right)$. $D_{i(0.025)}$ and $D_{i(0.975)}$ are the upper and lower confidence limits obtained for $D_{i}$ after 10,000 randomizations. $P$ values are the proportion of all the $D_{i} s$ that are greater than or equal to $D_{0}$

\begin{tabular}{lllll}
\hline Sampling date & $\boldsymbol{D}_{\mathbf{0}}$ & $\boldsymbol{D}_{\boldsymbol{i ( \mathbf { 0 . 0 2 5 } )}}$ & $\boldsymbol{D}_{\boldsymbol{i ( \mathbf { 0 . 9 7 5 ) }}}$ & $\boldsymbol{P}$ \\
\hline May 2015 & 1.90 & -1.19 & 1.33 & 0.001 \\
November 2015 & 1.11 & -0.72 & 0.94 & 0.006 \\
\hline
\end{tabular}

Significant effects $(P<0.05)$ are marked in italics

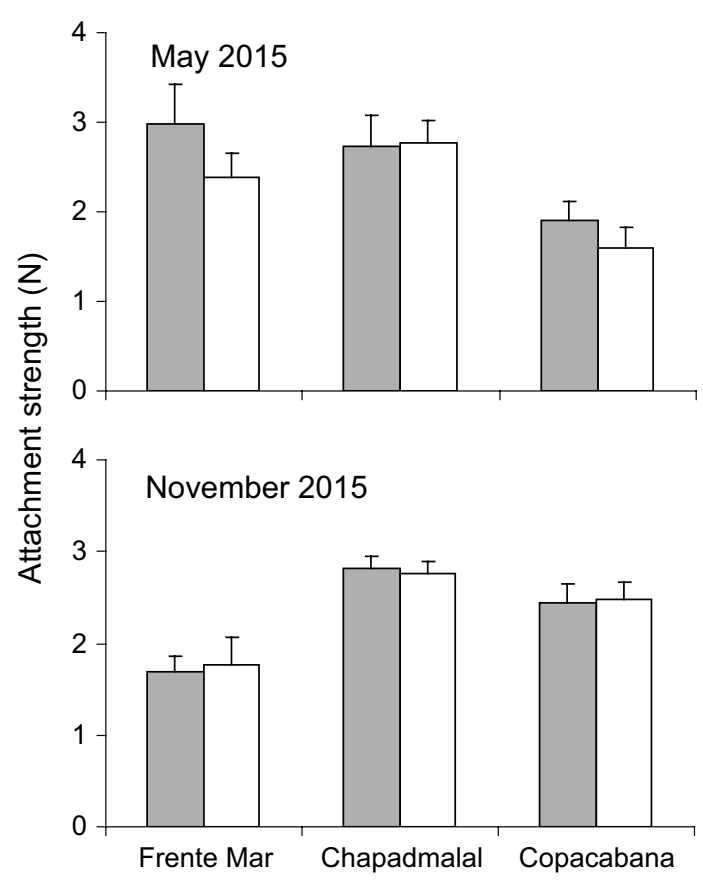

Fig. 3 Mean (SE) attachment strength of Brachidontes rodriguezii in natural platforms of loess cemented by calcium carbonate (soft rock, white bars) and orthoquartzite blocks introduced to form groins or revetments (hard rock, grey bars) at three rocky intertidal sites $(n=12)$

through wave refraction and convergence [39] - than straight and gently sloping loess shorelines (this is also apparent from our casual observations of relative wave splash across the study sites). Increased wave exposure could account for stronger mussel attachment in natural orthoquartzite sites, mostly if we consider that mussels can adjust their attachment strength to increased wave action by increasing byssus production $[3,8,16$, 17]. Other potentially confounding factors leading to increased attachment strength in orthoquartzite sites include reduced desiccation stress (orthoquartzite sites are more likely to remain splashed-out by waves during low tide; pers. obs.) and higher food quality (suspended particles may include a larger proportion of sediments at loess sites due to soft cliff erosion) [39], both of which might allow allocating a larger amount of energy to byssus production.

\section{Byssal thread counts and failure locations}

Similar attachment strength to loess and orthoquartzite at the local scale might either be due to (a) dislodgement primarily occurring via byssus failure (in which case rock type would be irrelevant for dislodgment) or, (b) mussels showing compensatory mechanisms to reduce their probability of dislodgement from friable substrates. Our data do not support the first alternative. Here we observed that the dislodgement of individual mussels from either rock type results from a combination of byssus and substrate failures. Since byssal thread failure comprises just ca. $30 \%$ of all failures per individual in either rock type (see Fig. 4c), it is insufficient to explain lack of variation in mussel attachment strength among rock types.

Our results rather suggest that mussels increase byssus production to compensate for increased potential of substrate failure when attaching to soft, friable rock. In agreement, mussels from loess showed more byssal threads, but a similar attachment strength than those from orthoquartzite (see Fig. 4a, b). Again, mussels from each rock type were sampled here from the same site and within a restricted radius ( $<10 \mathrm{~m}$; see "Methods" section), which suggests that differences in byssal thread numbers are unlikely driven by factors other than rock type. In conjunction, these findings are in line with early predictions made by Bell and Gosline [3], who argued that by producing more byssal threads, mussels would increase the area of substrate that is sampled by the byssus and, thus, the probability of encountering stable pieces of substrate in friable rock. Although similar considerations may apply to byssal thread thickness (i.e., more area sampled by thicker threads; see [3]), mussels from friable and hard rock here did not differ in this regard.

The larger proportion (and number) of rock failures observed in mussels from loess than orthoquartzite suggests that, in the absence of increased thread production, the potential for substrate failure and dislodgement should be higher for mussels attaching to soft, friable loess. This gives additional support to early claims from Bell and Gosline [3] on the ability of mussels to increase thread production to counteract substrate failure and reduce their risk of dislodgement from friable rock. 
Table 3 Results of mixed model, three-way ANOVA testing the effect of rock type, sampling date, and site on mussel attachment strength (In-transformed)

\begin{tabular}{lllll}
\hline Source & MS & $\boldsymbol{d f}$ & \multicolumn{1}{l}{$\boldsymbol{F}$} & $\boldsymbol{P}$ \\
\hline Rock type & 0.13 & 1 & 2.05 & 0.60 \\
Sampling date & 0.01 & 1 & 0.00 & 0.96 \\
Site & 1.52 & 2 & 0.79 & 0.56 \\
Rock type $\times$ sampling date & 0.09 & 1 & 1.25 & 0.38 \\
Rock type $\times$ site & 0.05 & 2 & 0.63 & 0.61 \\
Site $\times$ sampling date & 1.94 & 2 & 26.43 & 0.04 \\
Rock type $\times$ sampling date $\times$ site & 0.07 & 2 & 0.49 & 0.61 \\
\hline
\end{tabular}

Significant effects $(P<0.05)$ are marked in italics

\section{Ecomechanical considerations}

While the above findings suggest that rock type does not affect the potential for mussel dislodgement, it still remains to be evaluated if the observed values of mussel attachment strength can indeed be conducive to dislodgement. This can be explored by comparing mussel attachment strength against the forces acting on mussels at realistic flow velocities. Mussels occurring in beds are typically shielded by their neighbors from the drag and accelerational forces acting in the direction of water flow $[3,40]$. Thus, they can be assumed to be dislodged only by the lift force $\left(F_{\text {lift }}\right)$. Lift acts perpendicular to the flow and results from differences in pressure due to a higher flow velocity above the mussel bed than in its interstices [40]. Lift is related to the square of flow velocity $(U)$ and animal planform area $(A)$ as follows:

$$
F_{\text {lift }}=\left(\rho U^{2} A C_{l}\right) / 2
$$

where $\rho$ is the density of sea water $\left(1024 \mathrm{~kg} \mathrm{~m}^{-3}\right)$ and $C_{\mathrm{l}}$ is the dimensionless coefficient of lift. $\left(C_{1}=0.88\right.$ for bed mussels, which are generally oriented with its long axis perpendicular to the substrate; see $[3,40])$.

Figure 5 shows the theoretical lift forces acting on mussels 15-20 mm length (the range of mussel sizes in this study) at selected flow velocities $\left(3,6,9,12 \mathrm{~m} \mathrm{~s}^{-1}\right.$; see Additional file 4 for details on lift calculations). Here, critical flow velocities for mussel dislodgement are those leading to a lift force equivalent to mussel attachment strength (i.e., flow will dislodge mussels


Fig. 4 Mean (SE) byssal thread counts (a), attachment strength (b), and proportion of four failure locations (c) in individuals of Brachidontes rodriguezii from a natural platform of loess cemented by calcium carbonate (soft rock, white bars) and a groin made of orthoquartzite blocks (hard rock, grey bars), both sampled in April 2018 and located within the same site (Copacabana; $n=33$ for mussel attachment strength, $n=15$ for all the other variables) 
Table 4 Results of $t$-tests evaluating the effect of rock type on mean byssal tread counts, mean mussel attachment strength, and the mean proportion of four thread failure locations per individual mussel

\begin{tabular}{|c|c|c|c|}
\hline Variable & $d f$ & $t$ & $P$ \\
\hline Byssal thread counts ${ }^{\mathrm{a}}$ & 28 & 4.28 & $<0.01$ \\
\hline Attachment strength & 64 & 0.90 & 0.37 \\
\hline Thread failure (\%) & 28 & 0.49 & 0.63 \\
\hline Plaque failure (\%) ${ }^{\mathrm{a}}$ & 28 & 3.22 & $<0.01$ \\
\hline Rock failure (\%) & 28 & 2.99 & $<0.01$ \\
\hline Loose particle failure (\%) & 28 & 1.97 & 0.06 \\
\hline
\end{tabular}

Significant tests $(P<0.05)$ are marked in italics

a In-transformed data

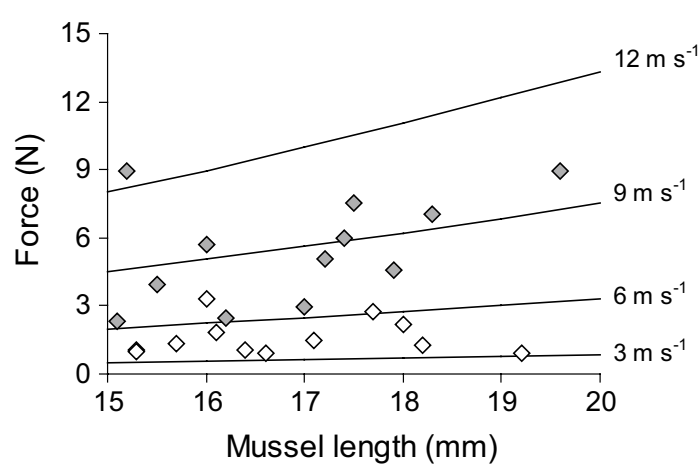

Fig. 5 Expected lift force acting on mussels within the size range used in this study (15-20 mm length) at selected flow velocities (3, 6,9 , and $12 \mathrm{~m} \mathrm{~s}^{-1}$; shown as continuous lines). Points are mussel attachment strength data obtained in May 2015 from the site with the weakest (Copacabana, loess platform, white diamonds) and strongest mussel attachment (Punta Iglesia, natural orthoquartzite platform, gray diamonds). The comparison of mussel attachment strength data and expected lift forces allows establishing a potential range of critical flow velocities for mussel dislodgment across our study area (i.e., $3-12 \mathrm{~m} \mathrm{~s}^{-1}$ )

when imposing on them a lift force that exceeds their attachment strength). Thus, from the lift necessary to dislodge mussels at the sites where they showed weakest and strongest attachment (i.e., Copacabana and Punta Iglesia respectively, May 2015; see Fig. 2b) we can predict that critical flow velocities are in the range of 3-12 $\mathrm{m} \mathrm{s}^{-1}$ across our study area (i.e., compare expected lift curves against attachment strength data shown as white and gray diamonds in Fig. 5). These critical flow velocities are either comparable or lower than those occurring at wave-swept rocky shores (i.e., up to $25 \mathrm{~m} \mathrm{~s}^{-1}$, typically less than $12 \mathrm{~m} \mathrm{~s}^{-1}$; see [41-44]) as well as to maximum flow velocities registered at one of these sites (Copacabana) using spring dynamometers (up to $12.65 \mathrm{~m} \mathrm{~s}^{-1}$ between April 25 and May 26, 2018; authors' unpublished data, see [42] for methods).

From the overlap in the range of critical and observed flow velocities, we can conclude that the values of mussel attachment strength registered here do not warrant resistance to dislodgement. Yet, the rates of mussel dislodgement at our study sites are certainly less than these numbers suggest. Indeed, from the above estimates alone it could be inferred that flow velocities equal or larger than $6 \mathrm{~m} \mathrm{~s}^{-1}$, which regularly occur in our study area and wave-swept rocky shores in general, would virtually extirpate mussels from sites where the mussel attachment strength is relatively weak ( $<3 \mathrm{~N}$; see Fig. 5$)$. Clearly, this is not the case here as we have observed persistent mussel cover over the past several years across all our study sites, including those where mussel mussel attachment was weaker (e.g., Copacabana, Las Brusquitas, Frente Mar, Atlántida; see Fig. 2b). Rates of mussel dislodgement lower than the expected based on lift and critical flow estimates have also been reported in a previous study [40]. Here we postulate that this mismatch could be due to the afore-mentioned ability of mussels to adjust their attachment strength to increased hydrodynamic forcing via enhanced byssal thread production $[3,8,16,17]$. As these responses to flow can be immediate [see 16, 40, $45]$, then measurements conducted during low tide and weather conditions benign enough for field work may underestimate the strength of mussel attachment at the time when wave action becomes more stringent.

\section{Implications for habitat stability and function}

Brachidontes rodriguezii [see 19-21] and bed-forming mussels in general [see 46-48 for reviews] are widely recognized as ecosystem engineers that generate physical habitat to a variety of other organisms. From the fact that B. rodriguezii attaches to a similar strength in hard and friable substrates within a given locale, we can conclude that substrate hardness and friability per se will not influence the structure and dynamics of the habitat that this species generates. Since mussel-associated organisms are largely influenced by the dynamics of mussel patch formation and decay $[49,50]$, we can also predict that local dynamics in our mussel bed communities would be independent of the nature and friability of the basal substrate. Yet, this does not mean that human-introduced orthoquartzite blocks and natural loess outcrops would have similar habitat function. Clearly, the attachment of sessile organisms outside from mussel patches may still be affected by rock type. Moreover, it is also well known that orthoquartzite hardness prevents the establishment of the various endolithic invertebrates that inhabit loess platforms [51]. 
Lastly, it becomes clear from our local comparisons that the softness and friability of loess relative to orthoquartzite does not limit $B$. rodriguezii attachment and colonization. Again, this is also evident from the ability of mussels to form persistent beds both in orthoquartzite and loess [19-21]. Relatively stable and continuous mussel cover may armor loess against mechanical impacts while potentially insulating it from extreme heat flows. This implies that mussels could reduce the impact of wave forces and abrasion on intertidal loess, while also playing indirect "bioprotective" roles [52] via influences on microclimate that limit weathering-e.g., reduced fluctuations in rock temperature and moisture [53]. If this is the case, the ability of mussels to attach and form relatively stable cover on otherwise erodible rock might have important large-scale implications for coastal geomorphology and evolution, and for the persistence of intertidal loess habitats as a whole.

\section{Additional files}

Additional file 1. Location of sampling areas at sites with orthoquartzite groins and natural loess platforms.

Additional file 2. Local comparisons of mussel attachment strengthtests of anova assumptions.

Additional file 3. Byssal threads and failure locations-tests of student's t-test assumptions.

Additional file 4. Forces acting on mussels at specified flow velocities.

\section{Authors' contributions}

All authors contributed to study conception, study design, field research, interpretation of findings, and commenting on manuscript drafts. JLG and MB prepared the illustrations. JLG was primarily responsible for data analysis and the writing of manuscript drafts. All authors read and approved the final manuscript.

\section{Author details \\ 1 Grupo de Investigación y Educación en Temas Ambientales (GrlETA), Estación Biológica Las Brusquitas, B7783ADE San Eduardo del Mar, Argentina. ${ }^{2}$ Facultad de Ciencias Exactas y Naturales and CONICET, Universidad Nacional de Mar del Plata, Mar del Plata, Argentina. ${ }^{3}$ Museo Argentino de Ciencias Naturales "Ber- nardino Rivadavia" (MACN-CONICET), Buenos Aires, Argentina. ${ }^{4}$ Laboratorio de Reproducción y Biología Integrativa de Invertebrados Marinos (IBIOMAR- CONICET), Puerto Madryn, Argentina.}

\section{Acknowledgements}

We thank the Alfred Wegener Institute, Helmholtz Centre for Polar and Marine Research (AWI), for covering publication costs. This is a contribution to the program of GrIETA.

\section{Competing interests}

The authors declare that they have no competing interests.

\section{Availability of data and materials}

The datasets used and/or analyzed during the current study are available from the corresponding author on reasonable request.

\section{Consent for publication}

Not applicable.
Ethics approval and consent to participate Not applicable.

\section{Funding}

This research was funded by CONICET (Consejo Nacional de Investigaciones Científicas y Técnicas; PIP 11220110100024) to MGP and JLG, ANPCyT (Agencia Nacional de Promoción Científica y Tecnológica; PICT 2015 No. 2468) to MGP, and Total Foundation funds to SARCE (South American Research Group in Coastal Ecosystems). MB and LPA were supported by CONICET fellowships.

\section{Publisher's Note}

Springer Nature remains neutral with regard to jurisdictional claims in published maps and institutional affiliations.

Received: 28 February 2018 Accepted: 20 June 2018

Published online: 26 June 2018

\section{References}

1. Denny MW. Biology and the mechanics of the wave-swept environment. Princeton: Princeton University Press; 2008.

2. Denny MW, Daniel TL, Koehl MAR. Mechanical limits to size in waveswept organisms. Ecol Monogr. 1985:55:69-102.

3. Bell EC, Gosline JM. Strategies for life in flow: tenacity, morphometry, and probability of dislodgment of two Mytilus species. Mar Ecol Prog Ser. 1997;159:197-208.

4. Thomsen MS, Wernberg T. Minireview: What affects the forces required to break or dislodge macroalgae? Eur J Phycol. 2005;40:139-48.

5. Miller LP, O'Donnell MJ, Mach KJ. Dislodged but not dead: survivorship of a high intertidal snail following wave dislodgement. J Mar Biol Assoc UK. 2007:87:735-9.

6. Trussell GC. Phenotypic plasticity in the foot size of an intertidal snail. Ecology. 1997;78:1033-48.

7. Hunt HL, Scheibling RE. Predicting wave dislodgment of mussels: variation in attachment strength with body size, habitat, and season. Mar Ecol Prog Ser. 2001;213:157-64.

8. Carrington E. Seasonal variation in the attachment strength of blue mussels: causes and consequences. Limnol Oceanogr. 2002;47:1723-33.

9. Thomsen MS, Wernberg T, Kendrick GA. The effect of thallus size, life stage, aggregation, wave exposure and substratum conditions on the forces required to break or dislodge the small kelp Ecklonia radiata. Bot Mar. 2004;47:454-60.

10. Santos R, Flammang P. Intra-and interspecific variation of attachment strength in sea urchins. Mar Ecol Prog Ser. 2007;332:129-42.

11. Fletcher RL, Callow ME. The settlement, attachment, and establishment of marine algal spores. Br Phycol J. 1992;27:303-29.

12. Waite JH. Adhesion à la moule. Integr Comp Biol. 2002;42:1172-80.

13. Barnes $H$, Topinka JA. Effect of the nature of the substratum on the force required to detach a common littoral alga. Am Zool. 1969;9:753-8.

14. Milligan KLD, DeWreede RE. Variations in holdfast attachment mechanics with developmental stage, substratum-type, season, and wave exposure for the intertidal kelp species Hedophyllum sessile (C. Agardh) Setchell. J Exp Mar Biol Ecol. 2000;254:189-209.

15. Zardi GI, Nicastro KR, McQuaid CD, Rius M, Porri F. Hydrodynamic stress and habitat partitioning between indigenous (Perna perna) and invasive (Mytilus galloprovincialis) mussels: constraints of an evolutionary strategy. Mar Biol. 2006;150:79-88.

16. Price HA. An analysis of factors determining seasonal variation in the byssal attachment strength of Mytilus edulis. J Mar Biol Assoc UK. 1982;62:147-55.

17. Carrington E, Moeser GM, Thompson SB, Coutts LC, Craig CA. Mussel attachment on rocky shores: the effect of flow on byssus production. Integr Comp Biol. 2008:48:801-7.

18. Trovant B, Ruzzante DE, Basso NG, Orensanz JM. Distinctness, phylogenetic relations and biogeography of intertidal mussels (Brachidontes, Mytilidae) from the south-western Atlantic. J Mar Biol Assoc UK. 2013;93:1843-55. 
19. Penchaszadeh PE. Ecología de la comunidad del mejillín (Brachidontes rodriguezii D'Orb.) en el mediolitoral rocoso de Mar del Plata, Argentina: el proceso de recolonización. Physis. 1973;32:51-64.

20. Arribas LP, Bagur M, Klein E, Penchaszadeh PE, Palomo MG. Geographic distribution of two mussel species and associated assemblages along the northern Argentinean coast. Aquat Biol. 2013;18:91-103.

21. Adami ML, Tablado A, López-Gappa J. Spatial and temporal variability in intertidal assemblages dominated by the mussel Brachidontes rodriguezii (d'Orbigny, 1846). Hydrobiologia. 2004;520:49-59.

22. Gutiérrez JL, Palomo MG, Bagur M, Arribas LP, Soria SA. Wave action limits crowding in an intertidal mussel. Mar Ecol Prog Ser. 2015;518:153-63.

23. Escapa M, Isacch JP, Daleo P, Alberti J, Iribarne OO, Borges M, Dos Santos EP, Gagliardini DA, Lasta M. The distribution and ecological effects of the introduced Pacific oyster Crassostrea gigas (Thunberg, 1793) in northern Patagonia. J Shellfish Res. 2004;23:765-73.

24. Gutiérrez JL, Iribarne $\mathrm{OO}$. Role of Holocene beds of the stout razor clam Tagelus plebeius in structuring present benthic communities. Mar Ecol Prog Ser. 1999;185:213-28.

25. Salas MC, Defeo O, Narvarte M. Attachment features of mytilids in ecosystems with mobile substrate: Brachidontes rodriguezii in San Antonio Bay (Patagonia, Argentina). J Mar Biol Assoc UK. 2016;96:1449-56.

26. Scelzo MA, Elias R, Vallarino EA, Charrier M, Lucero N, Alvarez F. Variación estacional de la estructura comunitaria del bivalvo intermareal Brachidontes rodriguezi (D'Orbigny, 1846) en sustratos artificiales (Mar del Plata, Argentina). Neritica. 1996;10:87-102.

27. Torroglosa ME, Giménez J. Size at first maturity of Brachidontes rodriguezii (d'Orbigny, 1846) from the South-western Atlantic Ocean. J Mar Biol Assoc UK. 2016. https://doi.org/10.1017/S0025315416001636.

28. Isla FI. Erosión y defensas costeras. In: Isla Fl, Lasta CA, editors. Manual de manejo costero para la Provincia de Buenos Aires. Mar del Plata: Editorial de la Universidad Nacional de Mar del Plata; 2006. p. 125-47.

29. Zardi Gl, McQuaid CD, Nicastro KR. Balancing survival and reproduction: seasonality of wave action, attachment strength and reproductive output in indigenous Perna perna and invasive Mytilus galloprovincialis mussels. Mar Ecol Prog Ser. 2007;334:155-63.

30. Bagur M, Richardson CA, Gutiérrez JL, Arribas LP, Doldan MS, Palomo MG. Age, growth and mortality in four populations of the boring bivalve Lithophaga patagonica from Argentina. J Sea Res. 2013;81:49-56.

31. Lanfredi NW, Pousa JL, D'onofrio EE. Sea-level rise and related potential hazards on the Argentine Coast. J Coast Res. 1997;13:47-60.

32. Witman JD, Suchanek TH. Mussels in flow: drag and dislodgement by epizoans. Mar Ecol Prog Ser. 1984;16:259-68.

33. Schneider KR, Wethey DS, Helmuth BST, Hilbish TJ. Implications of movement behavior on mussel dislodgement: exogenous selection in a Mytilus spp. hybrid zone. Mar Biol. 2005;146:333-43.

34. Manly BFJ. Randomization, bootstrap and Monte Carlo methods in biology. London: Chapman \& Hall; 1998.

35. Quinn GP, Keough MJ. Experimental design and data analysis for biologists. Cambridge: Cambridge University Press; 2002.

36. Underwood AJ. Experiments in ecology: their logical design and interpretation using analysis of variance. Cambridge: Cambridge University Press; 1997.
37. Zar JH. Biostatistical analysis. Englewood Cliffs: Prentice-Hall; 1984.

38. Nicastro KR, Zardi Gl, McQuaid CD. Differential reproductive investment, attachment strength and mortality of invasive and indigenous mussels across heterogeneous environments. Biol Invasions. 2010;12:2165-77.

39. Limber PW, Murray AB, Adam PN, Goldstein EB. Unraveling the dynamics that scale cross-shore headland relief on rocky coastlines: 1 . Model development. J Geophys Res Earth Surf. 2014;119:854-73.

40. Denny MW. Lift as a mechanism of patch initiation in mussel beds. J Exp Mar Biol Ecol. 1987:113:231-45.

41. Denny MW. Wave forces on intertidal organisms: a case study. Limnol Oceanogr. 1985;30:1171-87.

42. Bell EC, Denny MW. Quantifying "wave exposure": a simple device for recording maximum velocity and results of its use at several field sites. J Exp Mar Biol Ecol. 1994;181:9-29.

43. Castilla JC, Steinmiller DK, Pacheco CJ. Quantifying wave exposure daily and hourly on the intertidal rocky shore of central Chile. Rev Chil Hist Nat. 1998;71:19-25.

44. Denny MW, Miller LP, Stokes MD, Hunt LJH, Helmuth BST. Extreme water velocities: topographical amplification of wave-induced flow in the surf zone of rocky shores. Limnol Oceanogr. 2003;48:1-8.

45. Young GA. Byssus-thread formation by the mussel Mytilus edulis: effects of environmental factors. Mar Ecol Prog Ser. 1985;24:261-71.

46. SuchanekTH. Mussels and their role in structuring rocky shore communities. In: Moore PG, Seed R, editors. The ecology of rocky coasts. London: Hodder \& Stoughton Press; 1985.

47. Gutiérrez JL, Jones CG, Strayer DL, Iribarne OO. Mollusks as ecosystem engineers: the role of shell production in aquatic habitats. Oikos. 2003;101:79-90.

48. Gutiérrez JL, Jones CG, Byers JE, Arkema KK, Berkenbusch K, Committo JA, Duarte CM, Hacker SD, Hendriks IE, Hogarth PJ, Lambrinos JG, Palomo MG, Wild C. Physical ecosystem engineers and the functioning of estuaries and coasts. In: Heip CHR, Philippart CJM, Middelburg JJ, editors. Volume 7: Functioning of estuaries and coastal ecosystems. Treatise on estuarine and coastal science. Amsterdam: Elsevier; 2011. p. 53-81.

49. Tsuchiya M, Nishihira M. Islands of Mytilus as a habitat for small intertidal animals: effect of island size on community structure. Mar Ecol Prog Ser. 1985;25:71-81.

50. Tokeshi M, Romero L. Filling a gap: dynamics of space occupancy on a mussel-dominated subtropical rocky shore. Mar Ecol Prog Ser. 1995;119:167-76.

51. Bagur M, Gutiérrez JL, Arribas LP, Palomo MG. Endolithic invertebrate communities and bioerosion rates in southwestern Atlantic intertidal consolidated sediments. Mar Biol. 2014;161:2279-92.

52. Carter NEA, Viles HA. Bioprotection explored: the story of a little-known earth surface process. Geomorphology. 2005;67:273-81.

53. Coombes MA, Naylor LA, Viles HA, Thompson RC. Bioprotection and disturbance: seaweed, microclimatic stability and conditions for mechanical weathering in the intertidal zone. Geomorphology. 2013;202:4-14.

Ready to submit your research? Choose BMC and benefit from

- fast, convenient online submission

- thorough peer review by experienced researchers in your field

- rapid publication on acceptance

- support for research data, including large and complex data types

- gold Open Access which fosters wider collaboration and increased citations

- maximum visibility for your research: over 100M website views per year

At BMC, research is always in progress.

Learn more biomedcentral.com/submissions 